
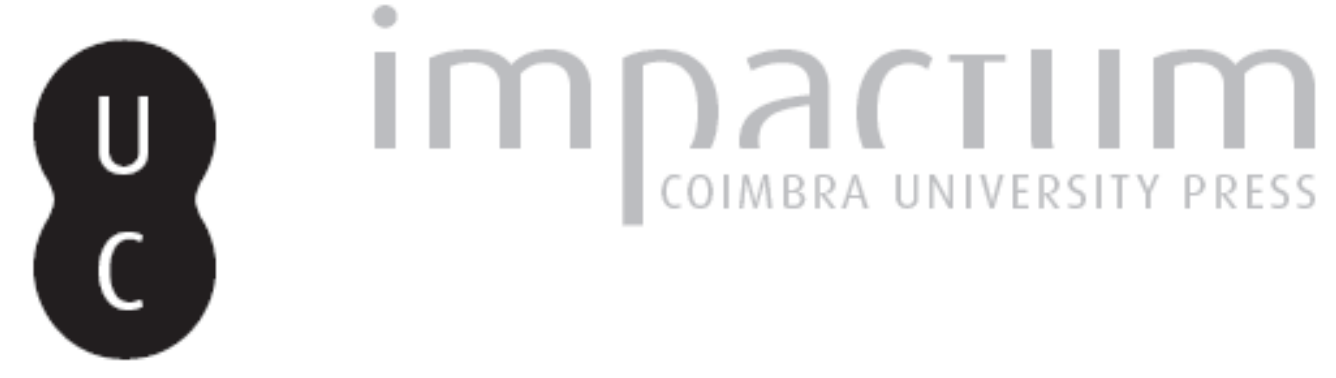

\title{
From governmental accounting to national accounting: implications on the portuguese central government deficit
}

Autor(es): $\quad$ Jesus, Maria Antónia; Jorge, Susana

Publicado por: Faculdade de Economia da Universidade de Coimbra

URL persistente:

URI:http://hdl.handle.net/10316.2/25231

DOI:

DOI:http://dx.doi.org/10.14195/2183-203X_31_2

Accessed : $\quad$ 26-Apr-2023 09:16:36

A navegação consulta e descarregamento dos títulos inseridos nas Bibliotecas Digitais UC Digitalis, UC Pombalina e UC Impactum, pressupõem a aceitação plena e sem reservas dos Termos e Condições de Uso destas Bibliotecas Digitais, disponíveis em https://digitalis.uc.pt/pt-pt/termos.

Conforme exposto nos referidos Termos e Condições de Uso, o descarregamento de títulos de acesso restrito requer uma licença válida de autorização devendo o utilizador aceder ao(s) documento(s) a partir de um endereço de IP da instituição detentora da supramencionada licença.

Ao utilizador é apenas permitido o descarregamento para uso pessoal, pelo que o emprego do(s) título(s) descarregado(s) para outro fim, designadamente comercial, carece de autorização do respetivo autor ou editor da obra.

Na medida em que todas as obras da UC Digitalis se encontram protegidas pelo Código do Direito de Autor e Direitos Conexos e demais legislação aplicável, toda a cópia, parcial ou total, deste documento, nos casos em que é legalmente admitida, deverá conter ou fazer-se acompanhar por este aviso.

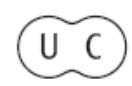




\section{N $\odot$ TASEC $\odot$ N}

\section{ANA CUNHA / JOSÉ RELEVANCIA INFORMATIVA DAS DESPESAS DE INVESTIGAÇÃO E DESENVOLVIMENTO: ANTÓNIO MOREIRA RELEVANCIA INFORMATIVA DAS DESPESAS D
UM ESTUDO PARA O CASO PORTUGUÊS}

MARIA ANTÓNIA JESUS / FROM GOVERNMENTAL ACCOUNTING TO NATIONAL ACCOUNTING: IMPLICATIONS ON SUSANA JORGE THE PORTUGUESE CENTRAL GOVERNMENT DEFICIT 

Implications on the Portuguese Central Government Deficit Maria Antónia Jesus / Susana Jorge ISCTE/Faculdade de Economia da U.C.

Partindo das diferenças mais relevantes entre a Contabilidade Pública (CP) perspectiva microeconómica - e a Contabilidade Nacional (CN) - perspectiva macroeconómica -, este artigo analisa os principais ajustamentos realizados em Portugal, na conversão dos dados do sector das Administrações Públicas, das Contas Públicas para as Contas Nacionais. Adicionalmente, avalia o impacto desses ajustamentos no défice da Administração Central, a maior parcela do défice público português.

Seguindo uma metodologia essencialmente qualitativa, o estudo empírico baseia-se em entrevistas realizadas junto dos responsáveis pela preparação das Contas Nacionais e em diversas fontes documentais. $\mathrm{O}$ objectivo é validar os ajustamentos identificados como mais significativos na passagem da CP para a $\mathrm{CN}$ e, ao mesmo tempo, avaliar o respectivo impacto nos dados notificados no âmbito do Procedimento relativo aos Défices Excessivos. Usaram-se dados da notificação de Abril de 2008, cobrindo o período compreendido entre 2004 e 2007.

Os principais resultados indicam que as diferenças de base contabilística são as mais relevantes e que os ajustamentos subsequentes têm um impacto significativo no défice da Administração Central portuguesa. Assim, esta investigação aponta para a necessidade de maior convergência entre os dois sistemas (CP e CN), nomeadamente quanto aos critérios de reconhecimento das transacções, por forma a ser adoptada uma base contabilística comum, e para um sistema informativo completo e coerente na CP.
Based on the relevant differences between Governmental Accounting (GA/microeconomic perspective) and National Accounting (NA/macroeconomic perspective) this paper examines the main adjustments made in Portugal to the General Government Sector data required to convert Governmental Accounts into National Accounts. It also assesses the impact of those adjustments on the Central Government deficit, the largest share in the Portuguese public deficit.

Following mostly a qualitative research methodology, the empirical study is based on interviews to officials preparing NA and on several documental sources. The purpose is to validate the major data adjustments from GA into NA regarding Central Government, while, in addition, assessing their impact using data from April 2008 Excessive Deficit Procedure notification, covering the 2004-2007 period.

The main findings indicate that differences concerning the accounting basis are the most relevant and that the subsequent adjustments have a considerable impact on the Portuguese Central Government deficit. This research points therefore to the need for more convergence between GA and NA, namely with respect to the transactions recognition criteria in order to use a common accounting basis, and for a complete and coherent reporting information system in GA.

Classificação JEL: H61, E62 
The existence of Governmental Accounting (GA) can be traced to centuries ago. It was initially viewed as an important tool in the transition from an «absolute-power» model of government to new forms of shared power. By then rulers had to count their expenditures in order to know how much taxes to collect. GA was then an instrument for the People to limit the Sovereign's power to spent public money, to collect taxes and to decide on the type of expenditures (Borgonovi and Anessi-Pessina, 1999). National Accounting (NA), in turn, is much more recent, and accompanied the emergency of macroeconomics after the Great Depression, although the elaboration of a system of National Accounts was not made possible before the World War II, when for the first time issues regarding an internationally harmonized system were raised, leading to the first United Nations System of National Accounts in 1953, followed by revisions and new editions from 1960 to 1993 (Jones, 2000; Vanoli, 2005).

The purpose behind both systems seems to have been totally different: while GA has always aimed at preparing and managing the Government's budget, NA was aimed at calculating the key aggregate indicators (e.g. gross domestic product, volume growth, national income, disposal income, savings and consumption) so that the whole national economy could be evaluated, including comparisons with other countries' aggregates (Bos, 2008).

NA highlights the transactions between national institutional sectors (non-financial corporations, financial corporations, General Government, households and non-profit institutions serving households) and between them and other Nations, for the purposes of external accountability and decision-making at political and macro level (Cordes, 1996). NA systems work over an economics-based conceptual framework, whereas an accounting conceptual framework underlies GA systems (Pinto and Santos, 2005).

Therefore, one may argue that NA is not a true accounting system in the sense it is understood in business accounting, that is, it does not allow recording and reporting on each governmental entity's (separately or as a group) budgetary, financial and economic situation, as GA does, especially if one considers that the latter has started to follow business accounting principles and techniques, providing information for purposes of control and accountability (Jones, 2000). In any case, NA computes macro aggregates for a Nation as a whole and by institutional sector, including the General Government Sector. The source for these data is naturally the accounts at micro level, hence the relationship between the two systems and the need for a certain alignment, at the least, on the basic principles (Jones and Lüder, 1996; Lüder, 2000; Jones, 2000).

The relevance of studying the relationships between Governmental Accounting (GA microeconomic perspective) and National Accounting (NA - macroeconomic perspective) has been underlined by several authors, such as Cordes (1996), Jones and Lüder (1996), Lande (2000), Lüder (2000), Jones (2000), Montesinos and Vela (2000) and Keuning and Tongeren (2004).

The main issue that arises within the EU countries concerns whether the current Governmental Accounting systems are able to meet the requirements of the European System of National and Regional Accounts (ESA95), namely in what relates to the data provided by the General Government Sector (GGS), according to the definition of institutional sectors in ESA95 (§ 2.17). This is particularly important inasmuch as it has been politically established within the EU Treaty regarding budgetary discipline, that the convergence criteria would be assessed using data from the member-States' (harmonised) NA and not from GA, having the deficit limits been defined based only on the GGS (applying GA) and not on the whole economy (Jones and Lüder, 1996; Jones, 2000).

This aspect is very relevant to Portugal as well, as the country, as an EU member state, has to prepare the National Accounts according with ESA95 requirements, and to accomplish with the convergence criteria of the EU Treaty regarding budgetary discipline. Furthermore, the 
implementation of a Governmental Accounting reform, started in the early 1990s, is still in progress. The utmost step in this reform was the publication, in 1997, of the Chart of Accounts for Public Accounting (CAPA), which became the basic accounting framework for all governmental entities belonging to Central, Regional and Local Administration, except governmental business enterprises. Among others goals, CAPA aimed at «(..) obtaining essential elements in order to calculate the Public Administration values to National Accounts, very important to support the calculation and the assessment of the European Union Treaty convergence criteria» (Law-decree 232/97, Preamble, 7).

This paper has the following goals: (1) to identify, from a conceptual point of view, the main divergences between GA and NA; (2) to examine the qualitative and quantitative relevance of these differences in the Portuguese context; (3) to analyse the main adjustments to be made when converting GGS data from GA into NA in Portugal; and (4) to assess the quantitative impact of those adjustments on the Central Government deficit reported by Portugal under the Excessive Deficit Procedure (EDP).

The paper is divided into seven sections. The first three sections include a literature review. Section 2 discusses the relevance of studying the relationships between GA and NA, focusing on the EU context, while Section 3 identifies the major differences between the two systems. Section 4 briefly explains the major features of the recent GA reforms in Portugal, in order to show whether the new system meets the ESA95 requirements. Section 5 presents the framework of GGS reporting under the EDP Notifications context. Section 6 explains methodological issues. The findings for Portugal are presented in Section 7, in the following order: relative importance of the main differences between GA and NA (subsection 7.1); major data adjustments when shifting from GA into NA (subsection 7.2); and the relative impact on the Central Government deficit reported (subsection 7.3). Finally, some conclusions and suggestions for further developments are presented in Section 8.

\section{The relationship between Governmental Accounting and National Accounting in the European Union}

Council Regulation No. 2223/96 (and subsequent amendments) ${ }^{1}$ forced EU member-States to adopt ESA95 in preparing their National Accounts, so that from April 1999 on the information sent to the European Statistical Office (EUROSTAT) would have to conform to the new system. Additionally (ESA95, §1.04), one of the specific purposes of this system is to support the control of the European monetary policy, namely national aggregates such as GDP, deficit and debt (EUROSTAT, 1996).

ESA95 is therefore the conceptual framework for EU member-States' National Accounts. In spite of the great diversity of political and social systems, underlying ESA95, it must reach not only objectives of analysis and evaluation of the economy of all member-States as a whole, but also to observe and control their fiscal and economic policies individually, in order to sustain the European Monetary Union (Sierra Molina et al., 2005).

Achieving these objectives implies, on the one hand, developing a real harmonisation of the (new) GA systems and, on the other hand, aligning those systems with ESA95 requirements, so that the macroeconomic aggregates are credible and comparable. The purpose is to get accurate values for the ratios established in article 104 of the European Union Treaty (1992) ${ }^{2}$ and required

1 Council Regulation No. 448/98, Commission Regulation No. 1500/2000, Parliament and Council Regulation No. 2516/2000, Commission Regulation No. 995/2001, Parliament and Council Regulation No. 2258/2002, Commission Regulation No. 113/2002.

2 Article 104 of the Maastricht Treaty states that «The member-States must avoid excessive deficits; The Commission has the power to observe the evolution of the budgetary situation and the amount of the governmental debt in the member-Sates and to monitor: whether the ratio of the planned or actual governmental deficit over gross domestic product exceeds a reference value (currently $3 \%$ ), unless the ratio has declined 
by the Protocol on the Excessive Deficit Procedures ${ }^{3}$ for assessing and monitoring the budgetary discipline of EU member-States under the EMU (Lüder, 2000; Benito López et al., 2005a).

According to Lüder (2000), the comparability of those ratios between countries requires a certain degree of international standardisation of definitions and procedures, and Governmental Accounting in the EU countries does not meet this harmonisation requirement neither in concepts nor in practices. This is the reason why the macroeconomic aggregates, such as the GDP and also the government deficit and debt, ought to be based on National Accounting.

Nevertheless, the problem of getting proper governmental sector data to National Accounts still remains. The data are obtained from Governmental Accounting, whose diversity and divergences from the macro accounting systems impairs the relevance, reliability and comparability of the aggregates that sustain the financial decisions of the EU member-States (Lüder, 2000 and Sierra Molina et al., 2005).

Montesinos and Vela (2000) explain that the main macroeconomic aggregates (e.g. deficit and debt) must have exactly the same meaning in governmental financial statements or in the National Accounts, otherwise usefulness and reliability of both accounting systems information may be significantly reduced. These authors also argue that governmental «(..) accounting information has a very important role to play in this process, as a useful tool for guaranteeing transparency and comparability among European countries and for economic, financial and management decision making" (Montesinos and Vela, 2000:129).

Lüder (2000) adds that the course of GA reforms that have occurred in most European countries, with a tendency towards 'disharmonisation', has affected in a negative way the links to NA, increasing the inconsistency between the two systems and leading to procedures of 'creative accounting', derived from divergences between the scope of the reporting entities and the accounting basis.

Montesinos and Vela (2000) also argues that certain practices of 'creative accounting' were adopted by several EU countries in order to offer a picture of convergence in the EMU, such as new methods for funding capital assets, delay in recognition of budgetary expenditures, and public debt decentralisation (public sector corporatisation).

The relationship between GA and NA has become relevant for several reasons (Cordes, 1996; Jones and Lüder, 1996; Lüder, 2000; Lande, 2000; Montesinos and Vela, 2000; Martí López, 2004; Sierra Molina et al., 2005; and Benito et al., 2005a, 2006):

- The aggregates of NA related to the governmental sector are based on GA, so the convergence of these two systems is needed to assure reliability and accuracy of the output data that ultimately sustain the political decisions under de Stability and Growth Pact;

- The figures on NA aggregates are the basis for the EU political and fiscal decisions;

- The adoption of full accrual basis for the majority of transactions, according to the last revision of ESA95, compulsory for all EU members-States for preparing their National Accounts and from which the convergence criteria established in article 104 of the Maastricht Treaty (1992) are monitored ${ }^{4}$;

- The GA reforms in progress in several OECD countries, especially in the EU member-States, moving from cash-based to accrual-based accounting systems and considering the value; whether the ratio of governmental debt over gross domestic product exceeds a reference value (currently $60 \%$ ), unless the ratio is sufficiently diminishing and approaching the reference value at a satisfactory pace». 3 Council Regulation No. 3605/93, modified by Council Regulation No. 475/2000, Commission Regulation (EC) n. ${ }^{\circ} 351 / 2002$ and Council Regulation (EC) No. 2103/2005.

4 See footnote 6 below. 
controversial introduction of accrual-based budgets, given that the source of data from GA for NA comes essentially from budgetary systems ${ }^{5}$.

\section{Differences between Governmental Accounting and National Accounting}

Though the studies about the relationship between GA and NA are rare, we have been analysing a few, including Cordes (1996), who focused his analysis on Germany, showing which improvements should be made in Governmental Accounting so that the data on the Governmental Sector meet ESA95 requirements. He emphasised, along with Jones and Lüder (1996), IFAC-PSC (2000) and Montesinos and Vela (2000), the following main differences between the two accounting systems:

- Divergences related to the definition of the reporting entity under the concept of 'Governmental Sector', as in NA the 'Governmental Sector' only includes public sector entities producing non-market goods and services;

- Differences related to the moment in which transactions are recognised, that occurs in a full accrual basis in the NA perspective (except for taxes recognition), while in the GA perspective both modified cash or modified accrual bases are still used as well6;

- Divergences related to the scope of the recorded transactions (the ESA95 requirement for recognising non-cash transactions, such as fixed assets depreciation, including infrastructures, not generally recorded in GA);

- Differences related to measurement criterion of recognised transactions, which NA considers to be the market price while in GA the historic cost (acquisition or production cost) is preponderant.

- Jones and Lüder (1996), following Cordes (1996), extended his analysis to the divergences between NA (SNA93 and ESA95) and GA in two EU countries (Germany and United Kingdom), developing a comparative study and underlining the following main issues:

- Contradictions between theory and practice the national aggregates computed under full accrual basis in NA and using modified cash basis in GA, and the implications on the determination of the ratios established by the EU Treaty;

- Divergences raising from the reporting entity definition, based on the concepts of institutional unit and institutional sectors and subsectors according to ESA95, and taking into account that some public sector entities are not included in the GGS sector in NA;

- Emphasis on the necessary adjustments to the figures provided by GA concerning the Governmental Sector due to different measurement criteria of assets and liabilities, reducing the reliability of the macroeconomic aggregates.

The differences between GA and NA might be identified from a conceptual point of view too, relating to different users' needs, which imply different objectives for the information provided by both systems. These differences imply others in the accounting principles adopted by each system, namely recognition and measurement criteria (AECA, 2001; Rodríguez Bolívar and Ortiz Rodríguez, 2002; Sierra Molina et al., 2005; Benito et al., 2006).

5 Cortés $(2003,2005)$ explains that preparing resource-based budgets implies the adoption of generally accepted accounting principles and the preparation of financial statements for the Annual Budget, such as estimated Balance Sheet and Statement of Financial Performance.

6 According to the (full) accrual basis regime, transactions are recorded when the economic value is created, transformed or extinguished, regardless their payment or receiving, while in a cash basis regime, transactions are recorded when they are paid or received. Modified cash basis means that budgetary revenues and expenditures are recognised when the associated administrative decisions have been taken, regardless the time when the transactions associated with them occur. Modified accrual basis means that not all assets are recognised, namely some fixed assets as infrastructures, cultural assets and defence equipment (Montesinos and Vela, 2000). 


\section{Table 1 - GA versus NA: users' needs, information objectives and recognition and measurement criteria}

Issue Governmental Accounting

Governments, international organisations, taxpayers, members

USERS of the legislature, creditors, suppliers, media, employees and general public

\begin{tabular}{|c|c|c|}
\hline USERS' NEEDS & $\begin{array}{l}\text { Information about the financial } \\
\text { position, performance and cash } \\
\text { flows of an entity, useful for } \\
\text { decision making and evaluation } \\
\text { resource allocation }\end{array}$ & $\begin{array}{l}\text { Aggregated data for economic } \\
\text { analysis, decision making and } \\
\text { policy making }\end{array}$ \\
\hline \multirow[t]{2}{*}{ GOALS } & Management Analysis & Economic analysis \\
\hline & Financial and budgetary reporting & Fiscal policies decision making \\
\hline \multirow[t]{2}{*}{ OBJECTIVES } & Accountability & Analysis and evaluation \\
\hline & Decision making & $\begin{array}{l}\text { Providing information for preparing, } \\
\text { implementing and monitoring the } \\
\text { economic policies of the European } \\
\text { Monetary Union }\end{array}$ \\
\hline \multirow[t]{2}{*}{ RECOGNITION } & $\begin{array}{l}\text { Budgetary accounting - cash basis } \\
\text { or modified cash basis }\end{array}$ & \multirow{2}{*}{$\begin{array}{l}\text { Full accrual basis for all } \\
\text { transactions (monetary and non } \\
\text { monetary), except for taxes and } \\
\text { social contributions }\end{array}$} \\
\hline & $\begin{array}{l}\text { Financial accounting - cash basis } \\
\text { or accrual basis (modified accrual } \\
\text { basis or full accrual basis) }\end{array}$ & \\
\hline MEASUREMENT & $\begin{array}{l}\text { Historical cost - purchase price or } \\
\text { production cost }\end{array}$ & Market prices (main reference) \\
\hline
\end{tabular}

European Community institutions, governments, analysts and decision-makers of fiscal policies and other National Accounting
European Community institu
governments, analysts and d
-makers of fiscal policies and
social and economic agents (3) 5

We note that ESA95 general recognition criterion (full accruals) was later modified with respect to taxes and social contributions by the EU Parliament and Council Regulation (EC) No. 2516/2000, allowing member-States to use three different recognition methods:

- Accrual basis - recognition when the taxes generating factor occurs;

- Adjusted cash basis - recognition of taxes under cash basis sources, considering as much as possible, a time adjustment so that the amounts received can be attributed to periods when the economic activity generating the fiscal obligation occurs;

- Cash basis - whenever it is not possible to apply none of the other methods.

The International Public Sector Accounting Standards Board (IPSASB) has been playing an important role identifying the most important differences between the two accounting systems. This Board developed a working program concerning the convergence of IPSASs with the NA systems. Subsequently, in January 2005 a Research Report titled «International Public Sector Accounting Standards (IPSASs) and Statistical Bases of Financial Reporting: an analysis of Differences and Recommendations for Convergence» was published, with the purpose of identifying differences in financial reporting provided by the statistical-based accounting systems (NA prepared according to IMF's GFSM2001, SNA93 and ESA95) and the financial information reported under IPSASs (GA). This document, based on IPSASs issued up to June 2004, also makes recommendations in order to reduce or eliminate the divergences between the two accounting systems wherever it is possible (IPSASB, 2005). 


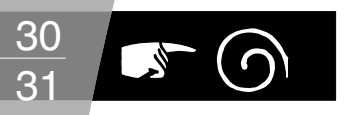

\section{Table 2 - GA versus NA: main divergences and issues Categories Issues}

The scope of the reporting entity and the scope of the sector reporting

- The boundaries of the reporting entities according to each accounting model

- Reporting components of the public sector, namely of the GGS

- Accounting for controlled entities

Recognition of assets, except financial instruments

- Definition of assets, liabilities, revenues, expenses and equity

- Specific issues, such as costs associated with research and development, other intangible assets, extractive industries and defence weapons

- Tax credits, tax gap and moment of recognising tax revenues

- Public-private partnerships

Measurement of assets, liabilities and net assets

- Several different criteria for measurement of each item, such (equity) as impairment of non-financial assets, transaction costs, low interests and interest free loans, inventories, investments in associates and biological assets

Source: Adapted from IPSASB (2005)

Table 2 shows those that we believe to be the main issues and problems, among others, identified on that document as key differences between accounting and statistical basis of financial reporting as at June 30, 2004 (IPSASB, 2005).

In short, our literature review allows us to identify the following major issues concerning the relationship between $\mathrm{GA}$ and NA:

- Definition and scope of reporting entity under GA and NA;

- Preparation and disclosure of consolidated financial statements;

- Recognition of taxes and social contributions - tax credits, tax gap and moment of recording tax revenues;

- Relationship between government and government business enterprises - privatisations, capital injections, government and government owned enterprises debt (notions of income and dividends).

Concerning the first issue, Lüder (2000) explains that while GA embraces almost all public sector entities (the exception being the Government Business Enterprises - GBEs), the GGS (S.13) under ESA95 includes only the institutional units that mainly provide non-market goods and services, intended for the general benefit of the community ${ }^{8}$.

On her turn, Lande $(2000,2006)$ emphasises that NA collects micro data from several institutional sectors that present different accounting principles and criteria, making it necessary some adjustments in order to harmonise the moment in which the transactions are recorded and the measurement criteria that must be applied to those transactions. She also suggests the need for harmonisation of the conceptual framework of the accounting systems of all sectors of activity, including GA systems, in which adjustments are needed while shifting into NA, particular with

7 Despite the changes in recognition criteria concerning taxes and social contributions, already mentioned, this is still considered an important difference because EU Member-states can use different methods, both in NA and in GA. 8 ESA95, §12, defines 'institutional units' as having decision autonomy as well as a complete set of accounts and ESA95 Manual of Government Deficit and Debt (EUROSTAT, 2002) identifies the necessary conditions so that an institutional entity might be included in the GGS (S.13): the unit must be public (controlled by the General Government Sector) and non-market (sales cover less than $50 \%$ of the production costs). The Manual also defines how the concept of 'economically significant prices' (the $50 \%$ rule) must be applied to public institutional units in order to classify them into the GGS (EUROSTAT, 2002). 
respect to the definition and scope of reporting entities and also concerning differences in classification, recognition dates and valuation methods.

More recently, Keuning and Tongeren (2004) emphasised the role of the adjustments, in a study of the relationship between GA and NA in Netherlands, in which they have highlighted the main steps that must be considered when taking data sources of Governmental Sector into NA:

- Transformation of cash-based (GA) into accrual-based (NA) data - identifying the proper asset and transaction category; consolidating some internal flows; adjusting time of recognition of taxes, interest payments on central government debt, payments in advance, among others;

- Transformation of accrual-based (GA) into accrual-based (NA) data - identifying the public entities market-oriented and also identifying the proper asset and transaction category and deconsolidate some internal flows.

\section{Governmental Accounting reform process in Portugal}

GA reform in Portugal has followed the trend observed in other countries, namely in the EU, under the New Public Management context (Vela Bargues, 1996; Brusca Alijarde, 1997; Brusca Alijarde and Benito López, 2002; Brusca and Condor, 2002; Benito and Brusca, 2004; and Benito et al., 2005b) ${ }^{9}$ :

- Adoption of generally accepted accounting principles, namely introducing the accrual basis regime, with a progressive approach to business accounting;

- Though the budgetary accounting system remains the most important, it has emerged as a subsystem of the Public Sector Management Information System;

- Harmonisation of the accounting systems between different levels of government;

- A more relevant role given to the accounting information for performance evaluation and management, as well as a tool for transparency and accountability;

- Development of public sector accounting information, clearly oriented to decision making and to the evaluation of public sector efficiency and effectiveness;

- Approaching GA and NA, so that adjustments, reclassifications and eliminations become easier and more reliable.

These changes in Portugal started at the beginning of the 1990s and many are still in progress. The main stages in the implementation of GA reforms in Portugal can be identified as shown in Table 3.

\begin{tabular}{c|c|c|}
\multicolumn{2}{|c|}{ Table 3 - Main stages of the Portuguese Governmental Accounting reform process } \\
\hline Stages & Period & \multicolumn{1}{c}{ Description } \\
\hline First Stage & $1990-1997$ & $\begin{array}{c}\text { • Public Accounting Bases Law (Law 8/90) and State Financial } \\
\text { Management New Regime (Law-decree 155/92) } \\
\text { - State Budget Framework (Law 6/91) }\end{array}$ \\
\hline Second Stage & $1997-2001$ & $\begin{array}{l}\text { - Chart of Accounts for Public Accounting (CAPA) - Law-decree } \\
\text { 232/97 } \\
\text { - Charts of Accounts for Public Administration subsectors } \\
\text { (Local Government, Education, Health and Social Security) }\end{array}$ \\
\hline Third Stage & 2001- & $\begin{array}{l}\text { - Improvements in the budgetary system - new State Budget } \\
\text { Framework (Law 91/2001) }\end{array}$ \\
\hline
\end{tabular}

9 New Public Management (NPM) is a movement started in the early 1980s in order to introduce in Public Administration principles and tools applied to private sector business management. Embracing a very large scope regarding management issues, specifically in what concerns financial and accounting systems, NPM has introduced accrual accounting in Public Sector entities so that GA can provide useful information for decision making and accountability (Olsen et al., 2001). 
The reform process has begun with the Public Accounting Bases Law followed by the establishment of the State Financial Management New Regime, according to which the accounting systems for Public Administration entities are:

- For Services Administratively Autonomous (general regime): modified cash-based budgetary accounting (cash basis with commitments for expenditures);

- For Autonomous Services (exceptional regime - services with property, budgetary, treasury and borrowing autonomy): accrual-based financial/patrimonial accounting along with modified cash-based budgetary accounting.

Meanwhile, in 1991, a law for the State Budget Framework was passed, setting the principles and rules for the budget preparation and execution. In 2001 this law was revoked and a new State Budget Framework law was issued, reinforcing the need for the Chart of Accounts for Public Accounting (CAPA) to be applied to all public sector entities as an important management tool (Law 91/2000 - article 10).

However, the landmark of the governmental accounting innovations in Portugal is CAPA, published in 1997. It was «(...) a fundamental step in the financial management and governmental accounting reform (...)" (Law-decree 232/97, Preamble, 1). This step was decisive to introduce accrual-based accounting in governmental entities, aiming at the «(...) determination of efficiency and effectiveness indicators related to the use of public money and, simultaneously, at the establishment of conditions required to prepare a Whole State Balance Sheet» (Caiado and Pinto, 2002: 40).

According to Carvalho et al. (1999), GA should continue with traditional objectives of legal control associated to budgetary accounting but, at the same time, it must include recent purposes related to assessing economy, efficiency and effectiveness in decision making, implying the introduction of financial and cost accounting. Caiado and Pinto (2002) also explain that until the publication of CAPA, in 1997, GA was understood as a set of rules for the budget approval, accomplishment and control, in order to judge the corresponding responsibilities. But this traditional budget-oriented governmental accounting, concerned with an overall purpose of legal accountability of the sources and uses of financial resources, with a single-entry booking method, neither has allowed evaluation of the patrimonial and financial situation of reporting entities nor has provided useful information for management.

The main goal of CAPA was «(...) to create conditions for the integration of different accounting perspectives - budgetary, patrimonial and cost accounting - in a modern governmental accounting system, which is a fundamental instrument to support governmental entities management and evaluation» (Law-decree 232/97, Preamble, 6).

\begin{tabular}{|c|c|c|}
\hline Perspective & Objective & Purposes \\
\hline $\begin{array}{l}\text { Budgetary } \\
\text { Accounting }\end{array}$ & $\begin{array}{l}\text { Strategic decision } \\
\text { making on budgetary } \\
\text { field }\end{array}$ & $\begin{array}{l}\text { - Preparation of budgets for more than one year } \\
\text { - Monitoring obligations with effects in future years } \\
\text { - Monitoring the annual budget accomplishment }\end{array}$ \\
\hline $\begin{array}{l}\text { Financial/ } \\
\text { Patrimonial } \\
\text { Accounting }\end{array}$ & $\begin{array}{l}\text { Providing information } \\
\text { about each entity's } \\
\text { financial position and } \\
\text { economic performance }\end{array}$ & $\begin{array}{l}\text { - Support for controlling the financial activity of all } \\
\text { public sector entities } \\
\text { - Providing accountability and transparency } \\
\text { - Providing more transparency about the entities } \\
\text { financial/patrimonial position }\end{array}$ \\
\hline $\begin{array}{c}\text { National } \\
\text { Accounting }\end{array}$ & $\begin{array}{l}\text { Providing the } \\
\text { necessary data to } \\
\text { determine the } \\
\text { macroeconomic } \\
\text { aggregates for the } \\
\text { National Accounts }\end{array}$ & $\begin{array}{l}\text { - Assessing and monitoring commitments derived } \\
\text { from the budgetary discipline that all EU member- } \\
\text {-States have to comply - the convergence criteria } \\
\text { established in article } 104 \text { of the Maastricht Treaty } \\
\text { (1992) and the Stability and Growth Pact }\end{array}$ \\
\hline
\end{tabular}


Table 4 summarises CAPA main goals according to Law-decree 232/97 (Preamble, 7), covering the budgetary and financial/patrimonial perspectives and the National Accounting point of view as well. The following CAPA major characteristics can be underlined (Caiado and Pinto, 2002):

- Though continuing considering issues related to budgetary accomplishment, the accounting system became more oriented to patrimonial, economic and financial issues.

- Both financial and budgetary transactions are recorded under a double-entry bookkeeping method;

- Financial and budgetary accounting, although using distinctive accounts, are integrated in one single accounting system, that should also integrate cost accounting;

- Full accrual basis for financial transactions and modified cash basis for budgetary transactions.

Therefore, the CAPA integrated system uses simultaneously two accounting bases in a clear divergence with the NA system - ESA95 which is full accrual-based (except for transactions regarding taxes and social contributions) and demands for Balance Sheets showing the sectors net worth and respective changes. Divergences may also be found in other areas, for example concerning the assets measurement criteria - historical cost (CAPA) versus market price (ESA95), or the identification of the reporting entity.

Moreover, using the annual activities reports of the Portuguese Public Administration Accounting Standardisation Commission (CNCAP, 2005, 2006, 2007) it can be seen that CAPA has been implemented almost exclusively in the autonomous services (with administrative and financial autonomy), while the administratively autonomous services (only with administrative autonomy) still apply a modified cash-based budgetary accounting system. This CAPA implementation problem emphasises the divergences to NA (essentially all accrual-based), considering the still relevant weight of administratively autonomous services in the Portuguese Central Government Sector, which makes the cash-based accounting still predominant.

Since 2001, Portugal has adopted a new State Budget Framework Law, as well as new rules for preparation and presentation of the annual budget (according to projects and programs) and for accountability of certain public entities under the control of several institutional bodies - e.g. The Court of Accounts (Supreme Auditing Body) and The Portuguese Republic Legislative Assembly (Parliament).

The reforms implemented in the second and third stage (c.f. Table 3) are still in progress, but it is important to underline that they have not included the accrual approach for the budgetary system, which is considered an important limitation to this reform process at the present stage. The legislative changes in this field so far have merely followed the international trends, introducing new practices for budgetary transparency, according to OECD (2001) recommendations, and new measures to accomplish with the requirements of Stability and Growth Programmes which all European member-States under the EMU are obliged to.

\section{GGS reporting under the EDP Notifications context}

The main legal establishments for the Excessive Deficit Procedure (EDP) Notifications concern the application of the Protocol on the EDP, as well as both ESA95 and ESA95 Manual on Government Deficit and Debt (EUROSTAT, 2002), with the subsequent updates ${ }^{10}$.

Nowadays, it is very relevant the so-called 'Institutional Cooperation Agreement' (INE et al., 2006) signed between the National Institute of Statistics (INE), the Budget General Department (DGO) and the Bank of Portugal (BdP). The main purpose of this agreement is the 
accomplishment of EU legislation about GGS statistics and the methodological harmonisation concerning data collection and compilation, as well as the update of sources and methods used in the preparation of National Accounts regarding the GGS.

Subsequently, a methodological document («Inventário de Fontes e Métodos relativo à compilação de dados no âmbito do Procedimento dos Défices Excessivos») was published in 2007 (hereafter designated as Inventory of Sources and Methods, INE, 2007). This document presents a description of sources and methods to be used in the preparation of EDP Notification TABLES.

Table 5 displays the notification periods for Reporting of Government Deficit and Debt Levels, according to EDP requirements.

\section{Table 5 - EDP Notification periods and status of data reported}

$$
1^{\text {st }} \text { Notification }
$$

April Notification of year $(\mathrm{N})$ to be submitted until the end of March of year $(\mathrm{N})$

October Notification of year $(\mathrm{N})$ to be submitted until the end

Source: Inventory of Sources and Methods (INE, 2007)

For example, April 2008 Notification includes planned data for this year, estimated data for 2007, half-finalised data for 2006 and final data for both 2005 and 2004. October 2008 Notification differs from the former because it presents already half-finalised data for 2007. For year 2008, final data will be reported only in 2010 April Notification.

In Portugal, according to the 'Institutional Cooperation Agreement' (INE et al., 2006), INE is responsible for coordinating the data compilation, except for the year of the $1^{\text {st }}$ Notification (these planned data are compiled by DGO). Furthermore, the Government deficit is determined by INE, while $\mathrm{BdP}$ is responsible for the Government debt. Therefore, INE is responsible for all reporting data to EUROSTAT.

Table 6 presents a brief description of the contents of each EDP Notification TABLE.

As our study is focused on Central Government, Table 7 identifies the main data sources used in the non-financial accounts, half-finalised and final data (planned and estimated data come only from DGO budgetary estimates), in April Notification, regarding Central Government accounting data ${ }^{11}$.

11 In NA, non-financial accounts refer to flows from transactions between institutional units related to expenses and revenues. The balance of these transactions relating to GGS is the governmental deficit/surplus, meaning the net borrowing/lending of Sector S.13. On the other hand, financial accounts deal with financial transactions (borrowing and lending) taking place between institutional units and show how the deficit is financed (or the surplus applied) by financial assets and liabilities. Otherwise, financial transactions are related to acquisition or amortisation of financial assets and liabilities (e.g. borrowing and lending; acquisition and sale of shares and other financial investments). Interest paid/received is however a flow included in non-financial accounts. 


\section{Table 6 - EDP reporting TABLES contents} Notification TABLES

TABLE 1

Deficit - Reporting of Government deficit/surplus and provision of

Deficit and Debt associate data for all GGS entities

Debt - Reporting of Government debt levels and provision of associate data for all GGS entities

TABLES 2 Data explaining the transition from governmental accounts budget deficit/surplus in GA into Government deficit/surplus in NA

There is one table for each Government level:

- Central Government - TABLE 2A

- Local Government - TABLE 2B

- Social Security - TABLE 2C

TABLES 3

Data explaining the contributions of deficit/surplus and other relevant factors to the debt level variation

There is one table for each Government level:

- General Government (GGS) - TABLE 3A

- Central Government - TABLE 3B

- Local Government - TABLE 3C

- Social Security - TABLE 3D

Source: Inventory of Sources and Methods (INE, 2007)

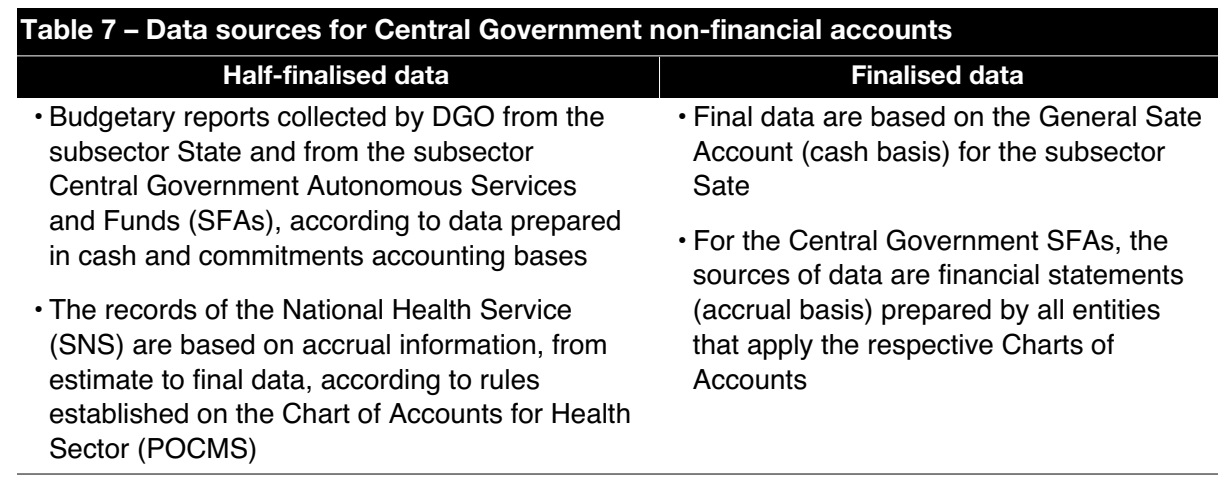

Source: Inventory of Sources and Methods (INE, 2007)

EDP Notifications periodical reports are prepared not only from different data sources but also using different accounting bases: for the half-finalised accounts all data are cash-based, except for the entities of the Ministry of Health, while the final accounts are cash-based for the State and accrual-based for SFAs. 


\section{Methodological issues}

Thus far we have followed mostly a qualitative methodology to describe, analyse and compare accounting practices, focalising on a particular context and pursuing a systematic and integrated approach (Miles and Huberman, 1994; Ryan et al., 2002).

One may also argue that a case study method has actually been used, as our approach allowed us to describe the accounting systems and examine the techniques and procedures in their practical setting, being a fieldwork applied to a specific country instead of a particular organisation (Ryan et al., 2002; Yin, 2003).

Qualitative studies sometimes use qualitative and quantitative data together (Miles and Huberman, 1994). In the former, several sources and research techniques have been used, such as analysis of documents, as well as semi-structured interviews, following the research lines designed by Yin (2003).

While the literature and the documental review were helpful in framing the problem and identifying the divergences between GA and NA, the interviews were designed for, say, validation purposes of the major differences across the two systems for the Portuguese case, as well as understanding their conceptual and quantitative relevance. The interviews were made to officials responsible in Portugal for the preparation of NA and EDP Notifications, from both INE and DGO. The semi-structured interviews were taped and occurred between December 2007 and March 2008.

Regarding the BdP, also responsible for the National Accounts, namely regarding the computation of the public debt, it was only possible to get written answers to a few questions related to data compilation and information about the quantitative relevance of the differences mentioned above.

The interviews were developed into two steps. Firstly, several preliminary and informal conversations occurred in order to get information about the major problems regarding the differences between GA and NA in Portugal. In a second step, we designed a guidance document comprising the most important issues to be treated in six main interviews to both INE and DGO officials, with an average length of 90 minutes each: (1) the relationship between GA and NA systems in Portugal; (2) the areas where differences between GA and NA are more significant and the reasons for specific accounting treatments; and (3) the determination of conceptual and quantitative relevance of differences previously identified.

The analysis of official documents, such as the Inventory of Sources and Methods (INE, 2007), allowed us, in a third stage, to identify the most important data adjustments (from GA into NA), namely concerning Central Government.

Finally, to assess the impact of those adjustments on Central Government deficit reported under EDP context, we used quantitative data, collected from TABLE 2 of the April 2008 Notification $\left(1^{\text {st }}\right.$ Portuguese Notification to EUROSTAT for this year) regarding Central Government deficit from 2004 to 2007, with a focus on the Central Government as its deficit represents more than $80 \%$ of the total GGS Portuguese public deficit (INE, 2008).

\section{Research findings}

\subsection{Main differences between GA and NA in Portugal}

The interviews made at INE and DGO, and the written answers from the Bank of Portugal, allowed us to identify the major differences between GA and NA and their relevance from each institution's point of view. Table 8 summarizes this information, and the interviews outcomes confirm the main differences identified on the literature review, which can be grouped in three categories: (1) the scope of the GGS; (2) the accounting bases and (3) the capital injections in State-owned corporations. 


\begin{tabular}{l} 
Conceptual relevance \\
\hline \multicolumn{1}{c}{ INE's int } \\
1. Definition of the General Government \\
Sector \\
2. Leasing transactions \\
3. Risk analysis of Public-Private Partnerships \\
(PPPs)
\end{tabular}

\section{Conceptual relevance
1. Definition of the General Government
Sector}

2. Accounting bases differences

\section{Quantitative relevance}

1. Adjustments cash/accrual for primary expenditures ${ }^{12}$

2. Accounting treatment of military equipment expenditures

3. Accounting treatment of taxes and social contributions - adjusted cash method

4. Capital injections, privatisations, etc. (questions related to the 'corporatisation' of public sector activities)

GO's interviews

Quantitative relevance

1. Versatility of the General Government Sector

2. Accounting bases differences (cash/accrual adjustments)

3. Capital injections in Government Business Enterprises (GBEs)

\begin{tabular}{|l|l|}
\hline \multicolumn{2}{|c|}{ BdP's answers } \\
\hline Conceptual relevance & \multicolumn{1}{c|}{ Quantitative relevance } \\
\hline Not identified & $\begin{array}{l}\text { 1. Accounting bases differences (cash/accrual } \\
\text { adjustments) }\end{array}$ \\
2. Transactions between GGS and GBEs
\end{tabular}

The first one is the most relevant but, similarly to category 3 , it does not imply standardized adjustments procedures, only occasional reclassifications in order to meet the requirements of ESA95 Manual on Government Deficit and Debt. This issue concerns the definition of the boundaries of the public sector entities in the institutional Sector S.13 (GGS) according to the Manual rules. These rules establish that a governmental entity must be included into the GGS only if it is a non-market institutional unity (which production is sold at economically significant prices) ${ }^{13}$. In Portugal INE is the institution responsible for applying these criteria, defining which governmental entities are to be included in the GGS.

\subsection{Data adjustments from Governmental Accounting into National Accounts}

The differences in the accounting bases involve data adjustments from GA into NA, made consistently in order to transform cash-based data into accrual-based data. The Inventory on Sources and Methods (INE, 2007) identifies the major following adjustments: (1) cash/accrual adjustments for taxes, social contributions, primary expenditures and interest, and (2) reclassification of some transactions, namely capital injections in State-owned corporations, dividends paid to GGS entities, military equipment expenditures and European Union grants.

Regarding taxes and social contributions, DGO makes data adjustments from cash to adjusted cash according to the exception to accrual basis allowed by Council Regulation (EC) No. 
Table 9 - Adjustments relating to accounting bases differences

\section{Issues} Adjustments

Taxes on tobacco, petrol and alcoholic beverages
[Cash-based revenue of year $(\mathrm{N})$

$+$

Revenue of year $(\mathrm{N})$ received in January of year $(\mathrm{N}+1)$

Revenue of year $(\mathrm{N}-1)$ received in January of year $(\mathrm{N})]$

\begin{tabular}{|c|c|}
\hline $\begin{array}{c}\text { Value Add Tax } \\
\text { (VAT) }\end{array}$ & $\begin{array}{c}\text { [Cash-based revenue of year }(\mathrm{N}) \\
+ \\
3 / 4 \text { of cash revenue of January and February of year }(\mathrm{N}+1) \\
- \\
3 / 4 \text { of cash revenue of January and February of year }(\mathrm{N})] .\end{array}$ \\
\hline $\begin{array}{c}\text { Primary } \\
\text { expenditures }\end{array}$ & $\begin{array}{c}\text { [Modified cash-based expenditures of year }(\mathrm{N}) \\
+ \\
\text { Expenditures of year }(\mathrm{N}) \text { in debt for year }(\mathrm{N}+1) \\
- \\
\text { Expenditures paid in year }(\mathrm{N}) \text { related to commitments of previous } \\
\text { years] }\end{array}$ \\
\hline Interest & $\begin{array}{c}\text { [Interest paid on year }(\mathrm{N}) \\
+ \\
\text { Interest occurred in year }(\mathrm{N}) \text { to be paid in year }(\mathrm{N}+1) \\
- \\
\text { Interest paid in year }(\mathrm{N}) \text { occurred in year }(\mathrm{N}-1)]\end{array}$ \\
\hline
\end{tabular}

Source: Inventory of Sources and Methods (INE, 2007)

2516/2000. For primary expenditures, the adjustments convert cash data (cash + commitments) into accrual data, based on information collected from a questionnaire sent to all public sector entities involved in cash-based accounts. Interest adjustments are made by the Portuguese Government Debt Agency (IGCP) that analyses loan by loan and security by security at the individual level in order to apply ESA95 rules. Table 9 shows several adjustments for these situations, concerning accounting bases differences.

The Inventory of Sources and Methods (INE, 2007) also distinguishes adjustments related to occasional reclassifications of some transactions, which require complementary information that is not available in the accounting records (i.e. General State Account or Financial Statements). Table 10 identifies those transactions, the data sources and the corresponding adjustments.

\subsection{Impact of the accounting differences on the Central Government Deficit}

The quantitative impact of the accounting differences on the Government deficit is assessed analysing data of TABLE 2A of EDP Reporting of Government Deficit - Moving from

Governmental Accounts into National Accounts. As shown in Table 6, EDP Reporting TABLE 2A provides data explaining the transition from Governmental Accounts budget deficit/surplus in GA into Central Government deficit/surplus in NA. We have used data from $20081^{\text {st }}$ Notification, containing final data for 2004 and 2005, half-finalised data for 2006 and estimated data for 2007. Data from 2008 were not analysed, since they were still in planned status (c.f. Table 5).

EDP Reporting TABLE 2A is based on the Governmental Accounts budget deficit to the subsector State (subsector S.13111) reported in the State General Account. It shows the following adjustments categories: (1) financial transactions that must be deducted from the State 


\begin{tabular}{c|c|}
\hline Transactions & Sources \\
\hline $\begin{array}{c}\text { Capital injections in } \\
\text { State-owned } \\
\text { corporations }\end{array}$ & Treasury \\
\hline & General \\
Department
\end{tabular}

\begin{tabular}{lll}
\hline Dividends paid to GGS & $\begin{array}{c}\text { Budget } \\
\text { General } \\
\text { Department }\end{array}$ & $\begin{array}{c}\text { - According to ESA95 Manual on Government Deficit } \\
\text { and Debt, each transaction is analysed in order to } \\
\text { determine whether the whole amount received from } \\
\text { dividends can be considered as an income with } \\
\text { positive impact on the deficit }\end{array}$ \\
\end{tabular}

- As it is stated in ESA95 Manual on Government Deficit and Debt, dividends are payments from a unit to Government, which are derived from the unit's income. Therefore, dividends do not apply to payments derived from assets sales, capital gains, or reserves accumulated over several years. This part of the dividends amount must be treated as withdrawals of equity, with no impact on deficit

\begin{tabular}{ccc}
$\begin{array}{c}\text { Military Equipment } \\
\text { expenditures }\end{array}$ & $\begin{array}{c}\text { Ministry of } \\
\text { Defence }\end{array}$ & $\begin{array}{c}\text { - Adjustments refer to the time difference between } \\
\text { paying for military equipment (time of recording in } \\
\text { the Government budget) and delivering military } \\
\text { equipment (recording moment in NA, following the } \\
\text { ESA95 rules) }\end{array}$ \\
\hline $\begin{array}{c}\text { EU grants } \\
\text { (neutrality of the }\end{array}$ & SFAs & $\begin{array}{l}\text { A survey is carried out to all units in order to } \\
\text { measure expenditures financed by EU grants, which } \\
\text { Community grants) }\end{array}$ \\
$\begin{array}{l}\text { are adjusted as follows: increased if revenues are } \\
\text { lower than expenditures, and decreased in the } \\
\text { opposite case, so that the direct effect of EU grants } \\
\text { is neutral for the deficit }\end{array}$ \\
\hline
\end{tabular}

budget deficit (GA) since in NA they represent Balance Sheet accounts, and therefore cannot be considered in the EDP deficit/surplus; (2) accounting basis adjustments for interest, accounts receivable and accounts payable; (3) balance (net borrowing or net lending) of other Central Government (CG) entities; and (4) other adjustments, such as capital injections, military equipment expenditures, leasing transactions, among others.

The differences relating the scope of GGS, although they cannot be separately shown, are eventually included in category 3, as stated in both 2006 and 2007 Reports on the State General Account. These reports explain, based on both April 2007 and April 2008 EDP Notifications, that those differences concern the inclusion of non-profit institutions, non-market corporations (e.g. Estradas de Portugal, EPE) and the exclusion of the quasi-corporations, respectively in or from the GGS boundaries (DGO, 2007, 2008). 


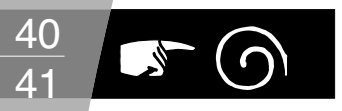

For the 2004-2007 period, in terms of the average relative weight for each category, the accounting basis adjustments represented the largest part (36\%), followed by the other adjustments (23\%) and by both financial transactions and balance of other CG entities adjustments (around 20\%).

In general terms, Figure 1 presents the comparison between the total amount of all adjustments and the Portuguese Central Government deficit (from GA, subsector State, before adjustments), showing that adjustments are greater to final and half-finalised accounts. Because these data incorporate more adjustments, they are more accurate, whereas estimated data integrate only a few initial adjustments. Therefore, the final Central Government deficit (NA) in 2004 decreased in about 2,500 millions $€$ regarding subsector State deficit $(\mathrm{GA})$, while in 2007 the final Central Government deficit (NA) increased about 268 millions $€$ regarding subsector State deficit (GA).

Figure 1 - Total of adjustments on the Central Government deficit in Portugal $\left(10^{3} €\right)$

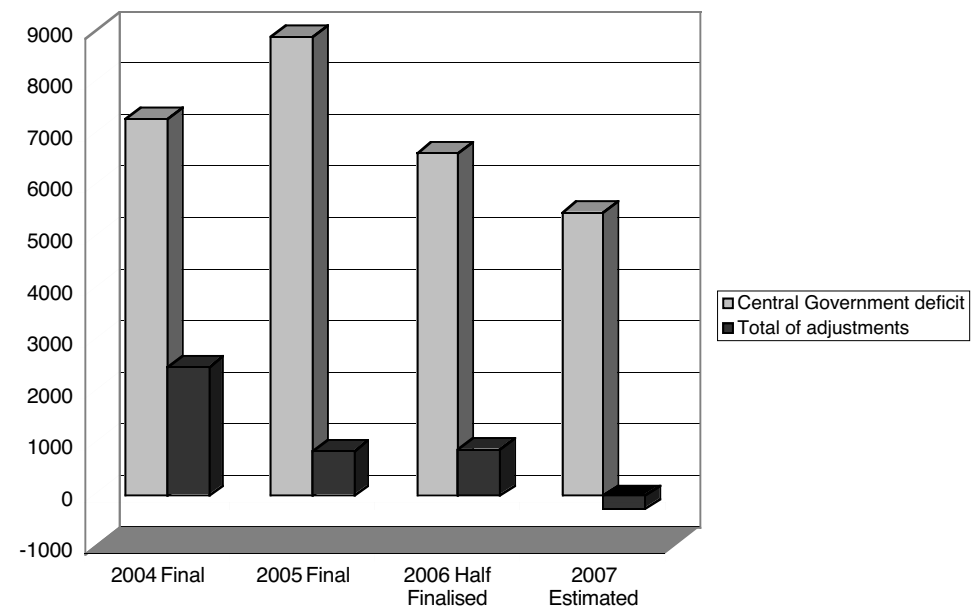

Figure 2 - Adjustments per category on the Central Government in Portugal (10 $€$ )

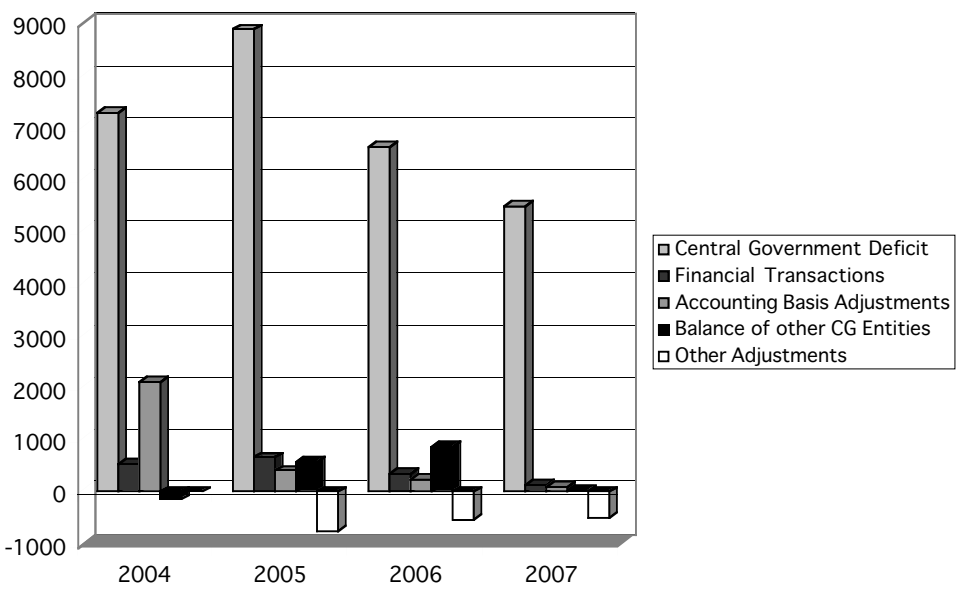


From Governmental Accounting to National Accounting: Implications on the Portuguese Central Government Deficit

Figure 2 indicates the amount of each category of adjustment on the Central Government deficit. It shows that the accounting basis adjustments category has the largest impact on the deficit earlier in the period (final data), while the balance of other CG entities has its highest impact in 2006. The other adjustments category, generally with a negative impact on the deficit, present larger amounts in the last three years and especially in 2005 , due to occasional reclassifications ilustrative of improved quality of data notifications.

Figures 3 and 4 display, in absolute terms, the evolution of the adjustments. It can be seen that in 2004 total adjustments reached the peak, mainly due to accounting basis adjustments.

Financial transactions adjustments show some stability, while the balance of other CG entities category/other adjustments category exhibits the highest value in 2006/2005.

\section{Figure 3 - Evolution of the total adjustments from GA into NA in Portugal - CG (10 $€$ )}

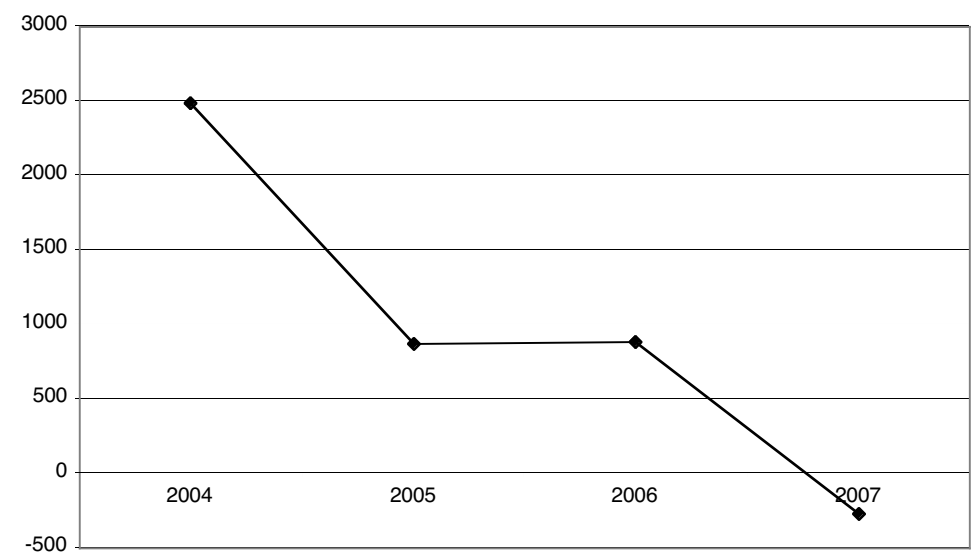

\section{Figure 4 - Evolution of adjustments per category from GA into NA in Portugal - CG (10 $€$ )}

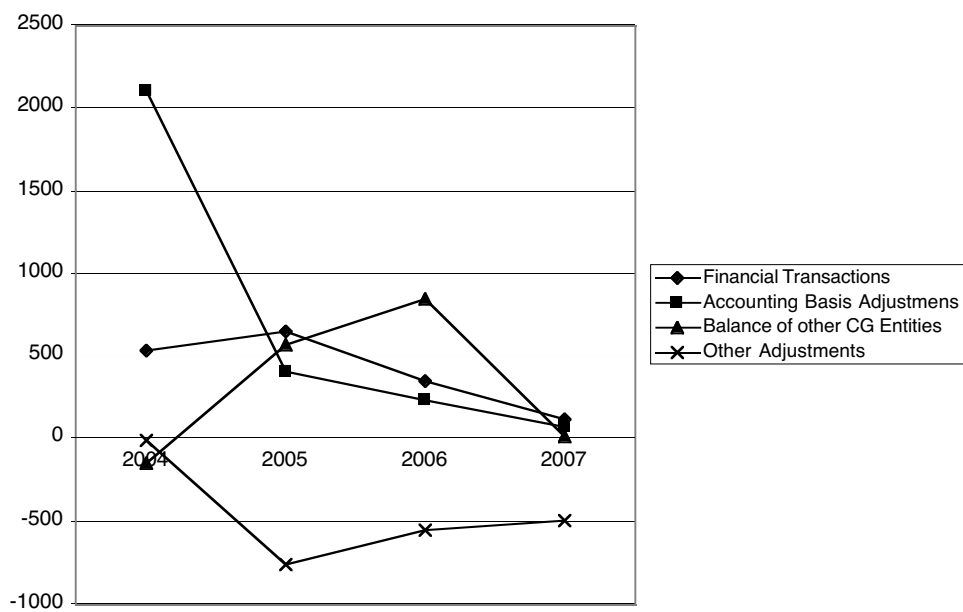




\section{Conclusions}

There are several divergences between Governmental Accounting and National Accounting from a conceptual point of view, namely concerning the criteria for transactions recognition (e.g. cash basis versus accrual basis) and measurement (historical cost versus market price). Differences can also be found in the scope of the reporting entity and in other relevant specific issues, such as those related to the preparation of consolidated financial statements and to the relationship between Government and Government Business Enterprises. Most of these differences have implications on the determination of macroeconomic aggregates.

Regarding Governmental Accounting, the reform process in Portugal has generally followed the practice of other European countries, moving from cash to accrual basis. Subsequently, it might be said that the convergence with macro accounting has been improved. But major differences still remain in place, namely in measurement criteria (historical costs versus market price), but also regarding the existence in GA of two different accounting bases - accrual basis for financial accounting and modified cash basis for budgetary accounting.

In turn, from the interviews to Portuguese officials involved in the preparation of NA related to GGS and the analysis of several documental sources, one may conclude that the main differences between GA and NA in Portugal are related: a) to the scope of the GGS; b) accounting basis (cash versus accruals), c) reclassification of certain transactions, such as capital injections in State-owned corporations. Based on the Inventory of Sources and Methods (INE, 2007), we have also identified the major adjustments related to the conversion of GA data into NA.

The quantitative impact of the reported differences on the Central Government deficit was based on the Portuguese EDP Reporting for Central Government (April 2008 Notification, TABLE 2A). The analysis of the impact in the 2004-2007 period has shown that the accounting basis differences became materially more relevant. It follows then the need for more convergence between the two systems - GA and NA - namely regarding the recognition criteria in order to use a common accounting basis.

This study is an attempt to quantify the impact on Central Government deficit arising from the transition from GA into NA. Further developments are of course required, as well as a more detailed analysis of the accounting basis differences. It would also be interesting to evaluate the impact of the accounting differences between the two systems on the Portuguese Central Government debt by analysing TABLE 3 of the EDP Reporting, prepared by the Bank of Portugal. 
Asociación Española de Contabilidad y Administración de Empresas, AECA (2001) Documento N. ${ }^{\circ}$, Marco Conceptual para la Información de las Administraciones Públicas, Madrid.

Benito, B. and Brusca, I. (2004) International Classification of Local Government Accounting Systems, Journal of Policy Analysis, 6(1), 57-80.

Benito, B., Brusca, I. and Montesinos, V. (2007) The Harmonization of Government Financial Information Systems: The Role of IPSASs, International Review of Administrative Sciences, 73(2), 293-317.

Benito, B., Moreno, M. R. and Bastida, F. J. (2005a) Budgetary Stability: Budgetary Measurement in the European Union, in A. Bourmistrov and F. Mellemvik (Eds.), International Trends and Experiences in Government Accounting, Oslo: Bodo Graduated School Business, 117-130.

Benito, B., Brusca, I. and Montesinos, V. (2005b) Local Government Accounting: an international empirical analysis, in A. Bourmistrov and F. Mellemvik (Eds.), International Trends and Experiences in Government Accounting, Oslo: Bodo Graduated School Business, 80-97.

Benito, B., Bastida, F. J. and Moreno, M. R. (2006) A proposal for a budget transparency index in Central Governments, in E. Lande and J. C. Scheid (Eds.), Accounting Reform in the Public Sector: Mimicry, Fad or Necessity, France: Universty of Poitiers, 101-129.

Borgonovi, E. and Anessi-Pessina, E. (1999) Accounting and Accountability in Local Government: a framework, in E. Caperchione and R. Mussari (Eds.), Comparative Issues in Local Government Accounting, Boston, Dordrecht and London: Kluwer Academic Publishers.

Bos, F. (2008) Uses of National Accounts: History, international standardization and applications in Netherlands, Eagle, Economics \& Statistics Working Paper, Berkel en Rodenrijs, Netherlands.

Brusca Alijarde, I. (1997) The Usefulness of Financial Reporting in Spanish Local Government, Financial Accountability and Management, 13(1), 7-34.

Brusca Alijarde, I. and Benito López, B. (2002) Panorama Internacional de la Contabilidad Pública, VII Jornada de Trabalho sobre Contabilidade Pública, ASEPUC, University of Murcia.

Brusca, I. and Condor, V. (2002) Towards the Harmonisation of Local Accounting Systems in the International Context, Financial Accountability and Management, 18(2), 129-162.

Caiado, A. C. P. and Pinto, A. C. (2002) Manual do Plano Oficial de Contabilidade Pública. 2. Edição, Lisboa: Áreas Editora.

Carvalho, J. B. C., Pina Martínez, V. and Torres Pradas, L. (1999) Temas da Contabilidade Pública. Lisboa: Rei dos Livros.

CNCAP - Public Administration Accounting Standardisation Commission (2005) Annual Activities Report of year 2004, Portugal, http://www.min-financas.pt/cncap/Index.htm

CNCAP - Public Administration Accounting Standardisation Commission (2006) Annual Activities Report of year 2005, Portugal, http://www.min-financas.pt/cncap/Index.htm

CNCAP - Public Administration Accounting Standardisation Commission (2007) Annual Activities Report of year 2006, Portugal, http://www.min-financas.pt/cncap/Index.htm

Cordes, U. (1996) The 1995 European System of National Accounts (ESA), Governmental Accounting Reforms and the Government Sector's Micro-Macro Link, Recent Developments, in Klaus Lüder (Ed.), Comparative International Governmental Accounting Research, Speyerer Forschungsberichte, 159, 1-20.

Cortés, J. L. (2003) Necesidad de Reformar los Presupuestos Públicos. El Presupuesto de 
Recursos, Paper presented at the XII Annual Conference of the Asociación Española de Contabilidad y Administración de Empresas (AECA), Cádiz.

Cortés, J. L. (2005) The International Situation vis-à-vis the adoption of Accrual Budgeting, Working paper presented at the $10^{\text {th }}$ CIGAR Conference, Poitiers, France.

DGO (Budget General Department) (2007) General State Account of year 2006, Ministry of Finance and Public Administration, Portugal.

DGO (Budget General Department) (2008) General State Account of year 2007, Ministry of Finance and Public Administration, Portugal.

EUROSTAT (1996) European System of National and Regional Accounts (ESA95), Luxembourg: Office for Official Publications oh the European Communities.

EUROSTAT (2002) ESA95 Manual on Government Deficit and Debt (EMGDD), Luxembourg: Office for Official Publications oh the European Communities.

EUROSTAT (2003) Capital Injections, update of ESA95 MGDD (Part II, Chapter 3), Luxembourg: Office for the Official Publications of the European Communities.

EUROSTAT (2004a) Classification of Funded Pension Schemes and Impact on Government Finance, update of ESA95 MGDD (Parte I, Chapter 1.3), Luxembourg: Office for the Official Publications of the European Communities.

EUROSTAT (2004b) Lump sum payments to Government in the Context of the Transfer of Pension Obligations, update of ESA95 MGDD (Parte II, Chapter 5.3), Luxembourg: Office for the Official Publications of the European Communities.

EUROSTAT (2004c) Long term contracts between government units and non-government partners (Public-private partnerships), update of ESA95 MGDD (Parte IV, Chapter 4.2), Luxembourg: Office for the Official Publications of the European Communities.

IFAC-PSC - International Federation of Accountants, Public Sector Committee (2000) Study 11, Governmental Financial Reporting: Accounting Issues and Practices, New York.

IMF (International Monetary Fund) (2001) Government Finance Statistics Manual (revised GFS Manual).

INE (National Institute of Statistics) (2007) EDP Consolidated Inventory of Sources and Methods - Inventário de Fontes e Métodos relativo à compilação dos dados no âmbito do Procedimento dos Défices Excessivos, National Accounts Department of INE, September, www.ine.pt.

INE (National Institute of Statistics) (2008) Reporting of Government Deficit and Debt Levels, $20081^{\text {st }}$ Notification, March, www.ine.pt.

INE (National Institute of Statistics), BdP (Bank of Portugal), and DGO (Budget General Department) (2006) Acordo de Cooperação Institucional no Domínio Instituto das Estatísticas das Administrações Públicas.

IPSASB (International Public Sector Accounting Standards Board) (2005) Research Report: International Public Sector Accounting Standards (IPSASs) and Statistical Bases of Financial Reporting: An Analysis of Differences and Recommendations for Convergence, New York.

Jones, R. (2000) National Accounting, Government Budgeting and the Accounting Discipline, Financial Accountability and Management, 16(2), 101-116.

Jones, R. and Lüder, K. (1996) The Relationship Between National Accounting and Governmental Accounting: State of the Art and Comparative Perspectives, Research in Governmental and Non-profit Accounting, 9, 59-78.

Keuning, S. and Tongeren, D. (2004) The Relationship between Government Accounts and National Accounts, with special reference to Netherlands, Review of Income and Wealth, 50 (2),167-179. 
Lande, E. (2000) Macro Accounting and Accounting Relationships in France, Financial Accountability and Management, 16(2), 151-165.

Lande, E. (2006) Accrual Accounting in the Public Sector: Between institutional competitiveness and the search for legitimacy, in Lande, E. and Scheid, J. (Eds.), Accounting Reform in the Public Sector: Mimicry, Fad or Necessity; France: University of Poitiers, 19-30.

Lüder, K. (2000) National Accounting, Governmental Accounting and cross-country comparisons of Governmental Financial Condition, Financial Accountability and Management, 16 (2), 117-128.

Martí López, C. (2004) Accrual Budgeting, Treatment of Key Budget Items and Implications for Fiscal Policy, Working paper presented at the $27^{\circ}$ Annual Congress of the European Accounting Association, Prague.

Miles, M. B. and Huberman, A. M. (1994) Qualitative Data Analysis, London: SAGE Publications.

Montesinos, V. and Vela, J. M. (2000) Governmental Accounting in Spain and the European Monetary Union: a critical perspective, Financial Accountability and Management, 16(2), 129-150.

Olson, O., C. Humphrey and J. Guthrie (2001) Caught in an Evaluatory Trap: A Dilemma for Public Services Under NPFM, The European Accounting Review, 10(3), 505-522.

Organization for Economic Cooperation and Development, OECD (2001) OECD Best Practices for Budget Transparency, PUMA/SOB: www.oedc.org.

Pinto, A. C. and Santos, P. G. (2005) Gestão Orçamental Pública, 1. ${ }^{a}$ ed, Publisher Team, Lisboa. Rodríguez Bolívar, M. and Ortiz Rodríguez, D. (2002) Contabilidad Pública versus Contabilidad Nacional: Comparación desde un enfoque conceptual, VII Jornadas de Trabajo sobre Contabilidad Pública, ASEPUC, University of Murcia.

Ryan, B., Scapens, W.R. and Theobald, M. (2002) Research Method and Methodology in Finance and Accounting, London: Academic Press.

Sierra Molina, G., Perez Lopes, J. A. and Duarte Atoche, T. (2005) Conceptual Analysis of Systems of National and Regional Accounts. Empirical Study of the Regional Accounts of Spain, Working paper presented at the XV Spanish-Portuguese Meeting of Scientific ManagementCities in Competition, Seville.

United Nations, World Bank, OECD, International Monetary Found, Commission of the European Communities (1993) System of National Accounts (SNA), New York.

Vanoli, A. (2005), A History of National Accounting, Fairfax, USA: IOS Press.

Vela Bargues, J .M. (1996) Latest Developments in Local Government Accounting in Spain, Financial Accountability and Management, 12(3), 205-224.

Yin, R. (2003) Case Study Research: Design and Methods, London: SAGE Publications.

\section{PORTUGUESE LEGISLATION}

Law 8/90, February 20 - Public Accounting Bases Law

Law 6/91, February 20 - State Budget Framework Law

Law 91/2001, August 20 - new State Budget Framework Law

Law-decree 155/92, July 28 - State Financial Management New Regime

Law-decree 232/97, September 3 - Chart of Accounts for Public Accounting 


\section{EU REGULATIONS}

Council Regulation (EC) No. 3605/93, November 22, 1993, on the application of the Protocol on the Excessive Deficit Procedure annexed to the Treaty establishing European Union [OJ L 332, 3.12.1993].

Council Regulation (EC) No. 2223/96, June 25, 1996, on the European System of National and Regional Accounts in the Community [OJ L 310, 30.11.1996].

Council Regulation (EC) No. 475/2000, February 28, 2000, amending the Council Regulation (EC) No. 3605/93 on the application on the application of the Protocol on the Excessive Deficit Procedure annexed to the Treaty establishing European Union [OJ L 058, 03.03.2000].

Regulation (EC) No. 2516/2000 of Parliament and Council, November 7, 2000, emending the common principles of the European System of National and Regional Accounts (ESA95) in the Community on taxes and social contributions, emending Council Regulation (EC) No. 2223/96 [OJ L 290, 17.11.2000].

Commission Regulation (EC) No. 351/2002, February 25, amending Council Regulation (EC) No. 2223/96, on the ESA95 references [OJ L 055, 26.02.2002].

Council Regulation (EC) No. 2103/2005, December 12 2005, amending Council Regulation (EC) No. 3605/93 as regards the quality of statistical data in the context of the Excessive Deficit Procedure [OJ L 337, 22.12.2005]. 